International Journal of Social Sciences and Humanities
Available online at http://sciencescholar.us/journal/index.php/ijssh
Vol. 2 No. 1, April 2018, pages: $24 \sim 32$
e-ISSN: 2550-7001, p-ISSN: 2550-701X
http://dx.doi.org/10.29332/ijssh.v2n1.74

\title{
Higher Order Thinking Skills Assessment towards Critical Thinking on Mathematics Lesson
}

\author{
CrossMark \\ I Wayan Widana a, I Made Yoga Parwata b , Ni Nyoman Parmithi c, I Gusti Agung Trisna Jayantika d, \\ Komang Sukendra e, I Wayan Sumandya ${ }^{\mathrm{f}}$ \\ Article history: Received 2 August 2017, Accepted in revised form 28 January 2018, Approved 3 February 2018, \\ Available online 6 February 2018

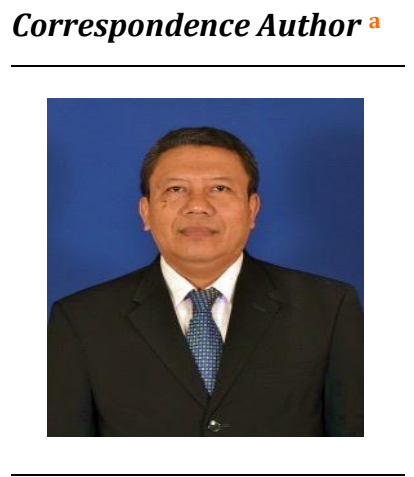

\begin{abstract}
The research was intended for analyzing the effectiveness of Higher Order Thinking Skills (HOTS) assessment towards critical thinking skills of high school students in Mathematics lesson. The subjects of this study were students XII-IPA class, SMA Negeri 8 Denpasar, the academic in 2017/2018. Sample selection in this study was applied random sampling technique. The research design used was post-test only control group design. The critical thinking of the student's skill was obtained through tests using HOTS assessment. The data were obtained and analyzed using ttest (2-tailed). The analysis results were to show that HOTS assessment could improve student's critical thinking skills in mathematics lesson effectively.
\end{abstract}

Keywords

Critical thinking; Mathematics lesson; High school students; Higher order thinking Skills assessment;
e-ISSN : 2550-7001, p-ISSN : 2550-701X ${ }^{\circ}$ Copyright 2018. The Author. SS Journals Published by Universidad Técnica de Manabí. This is an open-access article under the CC BY-SA 4.0 license

(https://creativecommons.org/licenses/by-sa/4.0/)

\footnotetext{
a Mathematics Program Studies, Faculty of Mathematics and Natural Sciences Education, Teacher Training Institute and Education Sciences of PGRI Bali

b Sports Education and Health Program Studies, Faculty of Sports Education and Health, Teacher Training Institute and Education Sciences of PGRI Bali

c Biology Program Studies, Faculty of Mathematics and Natural Sciences Education, Teacher Training Institute and Education Sciences of PGRI Bali

d Mathematics Program Studies, Faculty of Mathematics and Natural Sciences Education, Teacher Training Institute and Education Sciences of PGRI Bali

e Mathematics Program Studies, Faculty of Mathematics and Natural Sciences Education, Teacher Training Institute and Education Sciences of PGRI Bali

f Mathematics Program Studies, Faculty of Mathematics and Natural Sciences Education, Teacher Training Institute and Education Sciences of PGRI Bali
} 


\begin{tabular}{lll}
\hline Contents \\
Abstract \\
1. Introduction \\
2. Research Method \\
3. Results and Analysis \\
4. Conclusion \\
Acknowledgements \\
References \\
Biography of Author
\end{tabular}

\section{Introduction}

Ron Germaine et al. (2016) stated that a person needs mapping on essential competencies. The success achieved in the $21^{\text {st }}$ century has been formulated by experts in business, education, and other policy-makers who members of The Partnership for $21^{\text {st }}$ Century Skills (P21). In accordance with the framework that was proposed by National Education Association (NEA, 2012). The competencies were expressed in 4Cs: (1) Critical thinking and problem-solving. It is included reasoning ability, thinking, making good evaluation and decisions, and solving problems. (2) Communication defines an oral ability, written, and non-verbal communication in various forms, context, and technology; deciphering meaning and aiming; and communicate in diverse environments. (3) Collaboration defines workability in a diverse, flexible, willing to achieve common goals, gather responsibility for collaborative work, and respect for the individual contributions of the team members. (4) Creativity and innovation define a creative ability of the new idea and useful; describe, revise, analyze, and evaluate ideas to improve and maximize problem-solving efforts.

In order to achieve the essential competencies that are needed in the $21^{\text {st }}$ century. Three main components must be implemented comprehensively. (1) The more adaptive curriculum. The curriculum content development can inspire thinking and skills related to the time's challenges. (2) The more participatory learning model, the development of learning models directed to develop collaborative, interactive, creative, and innovative skills; and (3) the more meaningful assessment, namely the development of Contextual Assessment model and the demand for Higher Order Thinking Skill (HOTS). These three components should be run simultaneously and integrated (Andrew and Willingham, 2009).

Richard Paul \& Linda Elder (2006) defines Critical thinking as art for improving thinking skills in analyzing and evaluating specific problem-solving. A well-trained critical thinker has the ability to (1) formulating key questions and issues, formulating the problem clearly and precisely. (2) collecting and assessing relevant information, using abstract ideas to interpret them effectively. (3) resulting in a logical conclusion and be able to test it using certain criteria and standards. (4) Open minding in alternative thought systems, to recognize and assess, as needed, its assumptions, implications and practical consequences. (5) communicating effectively with others to find problems solutions.

The critical thinking skill in included: (1) problem analysis, critiquing arguments, and verification; (2) get conclusion using inductive or deductive reasoning; (3) assess and evaluate; and (4) make decisions or solve problems. Other capabilities identified are relevant to critical thinking including asking and answering questions for clarification, interpreting, and exploring, verbal reasoning, especially related to the concepts of possibility and uncertainty, predicting, and looking at problems from different reviews (Emily R. Lai \& Michaela Viering, 2012).

Critical thinking is a thinking skill that can be developed through learning and assessment in the classroom. Improving student's critical thinking skills in the schools. It can be done through (1) using learning models actively involve students in the learning process rather than relying on lectures, note, and memorization. (2) focusing lessons on the learning process and not just on materials. (3) using assessment techniques that require HOTS, giving students intellectual challenges and minimizing assessment only concerns memories (Peter, 2013).

Critical thinking (critical thinking skills) has become one of the tools used in our daily lives to solve some problems due to it involves logical reasoning, interpreting, analyzing, and evaluating information to enable a person to make reliable and valid decisions. In learning Mathematics, Critical thinking needs to be integrated and emphasized in the curriculum. Therefore, the students can learn skills and apply it, to improve their performance and reasoning abilities (A. N. Chukwuyenum, 2013). Based on the above description, it can be concluded that the

Widana, I., Parwata, I., Parmithi, N., Jayantika, I., Sukendra, K., \& Sumandya, I. (2018). Higher Order Thinking Skills Assessment towards Critical Thinking on Mathematics Lesson. International Journal Of Social Sciences And Humanities (IJSSH), 2(1), 24-32. doi:10.29332/ijssh.v2n1.74 
important aspects of the critical thinking skill. It is included the skill to analyze and solve problems, criticize arguments, verify, make conclusions using inductive or deductive reasoning, assess and evaluate, make decisions, interpret and explore, predict, and the skill to see problems from different reviews.

Mathematics as an important subject in modern society is used in the schools, workplaces, business and personal decision making. It is seen as a language for everyday purposes whether in the market, school or even at home. It is very important for the human progress and can be used as a tool to understand Science, Engineering, Technology and Economics (Kulbir, 2006). Mathematics is a universal science that is useful for human life and also underlies the modern technology development and has an important role in various disciplines and advance the human mind. The rapid development of the information and communication technology field today is based on mathematics development in some theories, algebra, analysis, probability theory, and discrete mathematics. In order to master and create technology in the future, it is necessary to mastering and comprehends great mathematics early (Regulation of the Minister of Education and Culture of the Republic of Indonesia No. 59 in 2014 on Curriculum 2013 High School/Madrasah Aliyah).

Mathematics subjects need to be given to all students, to equip them with logical, analytical, systematic, critical, innovative and creative thinking skills, as well as the ability to work together. These competencies are needed. Therefore, the students can have the ability to acquire, manage, and utilize information to live better in an ever-changing, uncertain and highly competitive state. In implementing mathematics learning, it is expected that the students should be able to feel the usefulness of learning math.

In fact, the student's critical thinking skills in mathematics subject are still very low. Mathematics learning generally in Indonesia often emphasizes on memorizing formulas aspects, calculating, or simply applying the simple concept. It should focus on developing logic, reasoning, argument, reasoning, analysis, and problemsolving. The assessment also tends to test only the ability to remember, the ability to calculate the formula, or simply apply the mathematical concept to a particular problem that is routine. The lower-level assessments in Bloom's Taxonomy (remembering, understanding, and applying) are categorized as Low Order Thinking Skills (LOTS) assessments. It is very rarely encountered the instrument used to test is an assessment that HOTS measures. The use of assessments only measure the remember skills, memorize formulas, or apply certain concepts to routine problems (LOTS), negatively impact student's mathematical critical thinking skills. The student's critical thinking skills will decline, even can be fatal in the form of the student's inability to solve problems in everyday life (Sri Hastuti Noer, 2009; In Hi Abdullah, 2013; Yoni Sunaryo, 2014).

Some experts define HOTS assessment as cited by Widana (2017) as follows. King, F.J., Ludwika Goodson., \& Faranak R. (2012) define HOTS included critical, logical, reflective, metacognitive, and creative thinking skills. This ability will develop when individuals encounter unfamiliar problems, uncertain conditions, or new phenomena that require solutions that have not been done before. HOTS assessment is an assessment that measures the three top levels in Bloom's Taxonomy, i.e., analyze, evaluate, and create (Anderson \& Krathwohl, 2001; Robert H. Ennis, 2014; Swartz and McGuinness, 2014). Whereas, Judith A, Salmon, \& Jennifer R (1987), stated that some abilities included in HOTS assessment: (1) problem solving, (2) decision making, (3) inferences (conclude), (4) divergent thinking skills, 5) evaluative thinking skills.

Widana (2016) stated that HOTS assessment is a measurement instrument used to HOTS measure, i.e., the ability to think not just remember (recall), restate, or refer without processing (recite). HOTS assessment measures capabilities: (1) transfer one concept to another, (2) process and implement information, (3) looking for links from different information, (4) use information to solve problems, and (5) review idea and information critically. Regarding the knowledge dimension, HOTS assessment measures the metacognitive dimension, rather than simply measuring factual, conceptual, or procedural dimensions. The metacognitive dimension illustrates the ability to connect several different concepts, interpret, solve problems, choose problem-solving strategies, and discover new methods, reasoning, and decision making.

Susan M. Brookhart (2010) stated that in order to improve student's critical thinking skills, HOTS assessment presents non-routine issues, the strategy for solving the problem is not explicitly seen. The problems that are not routine can explore and develop important aspects of critical thinking skills, i.e.:

Based on the above description, there is a relationship between HOTS assessment form and critical thinking ability. HOTS Assessment measures the ability to analyze, evaluate, and create (Bloom's taxonomy enhanced by Anderson \& Krathwohl (2011). Whereas, these abilities are important aspects of critical thinking skills. If the relevant skills at analyzing, evaluating, and creating are continuously honed using HOTS assessments. The student's theoretical critical thinking skills can be improved. Therefore, the use of HOTS assessment in 
educational assessment is an important issue that all education actors must respond to equip students to live in the $21^{\text {st }}$ century.

\section{Research Method}

The present research is quasi-experiment research. The effectiveness analyzed is HOTS assessment influence on critical thinking skills in the mathematics subjects of grade XII students in SMA Negeri 8 Denpasar. The research population is the students of grade XII students in SMA Negeri 8 Denpasar in 2017/2018, 343 students and is divided into nine classes. The sample selection using random sampling technique. Prior to sampling in XII students of MIPA in SMA Negeri 8 Denpasar, firstly conducted equality test for the student skills in the population using mathematics subject value. Data is analyzed using one-way ANOVA or often called the F-test. ANOVA test results are performed using SPSS 22.0 program. ANOVA (2-tailed) test output to test the population equality can be seen in Table 1 below.

Table 1

Equality Mathematics Skills Test

\begin{tabular}{lccccc}
\hline \multicolumn{7}{c}{ ANOVA } \\
\hline Value & Sum of Squares & df & Mean Square & F & Sig. \\
\hline Between Groups & 370,465 & 8 & 46,308 & 1,291 &, 247 \\
\hline Within Groups & 11981,716 & 334 & 35,873 & & \\
\hline Total & 12352,181 & 342 & & \\
\hline
\end{tabular}

The data in Table 1 shows that the F-value is 1.291 with the significance sig $=0.247>0.05$ (not significant). Conclusion: $\mathrm{H} 0$ accept, and $\mathrm{H} 1$ reject. The term means that there is no significant difference in the student's math skills in XII grade class population of MIPA in SMA Negeri 8 Denpasar. The mathematics skills are in the XII class population, MIPA specialization in SMA Negeri 8 Denpasar is equivalent. Thus, the samples selection can be conducted by random sampling technique. Then, the two randomly selected class XII MIPA-4 was selected 38 students as experimental class given treatment in the form of learning using HOTS and XII MIPA-6 as a control 37 students are given learning using LOTS assessment.

Independent variable in this research is HOTS assessment, whereas dependent variable is the student's critical thinking skills in the mathematics subject. Data on student's critical thinking skills are collected from test results using HOTS assessment, is given at the end of learning in both groups. HOTS assessment test used to data collection has previously been tested for its validity and reliability. The test result is then analyzed using $t$-test (2tailed) with a significance is 0.05 . Data is analyzed using SPSS 22.0 program.

\section{Results and Analysis}

HOTS assessment in the essay form is eight. To test the HOTS items eligibility that is used to collect the data of student's critical thinking skills on mathematics subjects, qualitative analysis is qualified experts, curriculum experts, and linguists are required. After analysis, all items are eligible to be tested. Furthermore, from eight points are selected five items to be tested. The test results show the test reliability is 0.74 . It means that the problems are very worthy to be tested. Data on the test of critical thinking ability of mathematics subjects in experimental group (XII IPA-4 Class) and control group (XII IPA-6 Class) are shown in Table 2 below.

Table 2

Data of Test Results of Critical Thinking Skills

\begin{tabular}{lccccc}
\hline & \multicolumn{6}{c}{ Group Statistics } \\
\hline & Class & N & Mean & $\begin{array}{c}\text { Std. } \\
\text { Deviation }\end{array}$ & $\begin{array}{c}\text { Std. Error } \\
\text { Mean }\end{array}$ \\
\hline $\begin{array}{l}\text { Nilai_Tes } \\
\text { Test } \\
\text { Value }\end{array}$ & XII IPA-4 & 38 & 83,89 & 5,501 &, 892 \\
\cline { 2 - 6 } & XII IPA-6 & 37 & 79,54 & 4,537 &, 746
\end{tabular}

Widana, I., Parwata, I., Parmithi, N., Jayantika, I., Sukendra, K., \& Sumandya, I. (2018). Higher Order Thinking Skills Assessment towards Critical Thinking on Mathematics Lesson. International Journal Of Social Sciences And Humanities (IJSSH), 2(1), 24-32. doi:10.29332/ijssh.v2n1.74 
To test the effectiveness of learning using HOTS assessment, firstly test the mean difference. The mean difference test of student's critical thinking skills in mathematics subjects is analyzed using $t$-test (2-tailed) with a significance is 0.05 . If there is a significant difference (mean) critical thinking skills of mathematics subject students significantly, means that the difference is caused by the treatment of learning using HOTS assessment. The results of the data analysis are shown in Table 3 below.

Table 3

Analysis Results of Difference of Critical Thinking Skills

\begin{tabular}{|c|c|c|c|c|c|c|c|c|c|c|}
\hline \multicolumn{11}{|c|}{ Independent Samples Test } \\
\hline & & $\begin{array}{r}\mathrm{L} \\
\mathrm{T} \\
\mathrm{Eq} \\
\mathrm{V}\end{array}$ & $\begin{array}{l}\text { ne's } \\
\text { for } \\
\text { ty of } \\
\text { aces }\end{array}$ & \multicolumn{7}{|c|}{ t-test for Equality of Means } \\
\hline & & \multirow[t]{2}{*}{$\mathrm{F}$} & \multirow[t]{2}{*}{ Sig. } & \multirow[t]{2}{*}{$\mathrm{t}$} & \multirow[t]{2}{*}{ df } & \multirow[t]{2}{*}{$\begin{array}{c}\text { Sig. } \\
(2- \\
\text { tailed) }\end{array}$} & \multirow[t]{2}{*}{$\begin{array}{c}\text { Mean } \\
\text { Differe } \\
\text { nce }\end{array}$} & \multirow[t]{2}{*}{$\begin{array}{c}\text { Std. Error } \\
\text { Differenc } \\
\mathrm{e}\end{array}$} & $\begin{array}{r}9 \\
\text { Conf } \\
\text { Interva } \\
\text { Diffe }\end{array}$ & $\begin{array}{l}\text { ace } \\
\text { f the } \\
\text { ice }\end{array}$ \\
\hline & & & & & & & & & $\begin{array}{c}\text { Lowe } \\
r\end{array}$ & $\begin{array}{l}\text { Up } \\
\text { per }\end{array}$ \\
\hline \multirow[t]{2}{*}{$\begin{array}{l}\text { Test_- } \\
\text { Value }\end{array}$} & $\begin{array}{l}\text { Equal } \\
\text { varian } \\
\text { ces } \\
\text { assum } \\
\text { ed }\end{array}$ & $\begin{array}{r}, 03 \\
3\end{array}$ &, 856 & $\begin{array}{r}3,73 \\
4\end{array}$ & 73 & ,000 & 4,354 & 1,166 & 2,030 & $\begin{array}{r}6,6 \\
78\end{array}$ \\
\hline & $\begin{array}{l}\text { Equal } \\
\text { varian } \\
\text { ces } \\
\text { not } \\
\text { assum } \\
\text { ed }\end{array}$ & & & $\begin{array}{r}3,74 \\
4\end{array}$ & $\begin{array}{r}71,0 \\
97\end{array}$ & ,000 & 4,354 & 1,163 & 2,035 & $\begin{array}{r}6,6 \\
73\end{array}$ \\
\hline
\end{tabular}

Table 3 above consists two sections, i.e., Levene's Test for Equality of Variances and t-test for Equality of Means. In Levene's Test for Equality of Variances, the section is seen that F-value is 0.33 with significance is 0.856> 0.05 (not significant), indicates that both groups samples have homogeneous variance. Thus, the hypothesis test using the $t$-test (2-tailed) can be continued. Furthermore, in the t-test for Equality of Means, is seen that the tvalue is 3.734 with significance $0,000<0.05$ (significant). It means that $\mathrm{H} 0$ reject and $\mathrm{H} 1$ accept which obtained that there is a difference of critical thinking skills of the students the following learning using HOTS assessment and LOTS assessment. The difference is caused by the influence of treatment given in the form of learning using HOTS assessment. Thus, it can be stated that learning using HOTS assessment effectively improves student's critical thinking skills in mathematics subjects.

In the experimental group, the student's critical thinking skills in mathematics subjects using HOTS based learning is better than LOTS assessment group. Critical thinking is a thinking skill that must be developed, trained, practiced, and integrated continuously in learning. Learning that is integrated HOTS assessment, can train student's thinking processes using mathematical logic. In accordance with its characteristics, HOTS assessment can make an important contribution to improve student's critical thinking skills including problemsolving skills, decision making, concluding, divergent thinking skills, evaluative thinking skills, and creative skills. What if the student's critical thinking skills can be achieved well. It is expected to improve the quality of learning especially to mastering the mathematical concepts learned in the classroom. That is, the mastery of the mathematical concepts can be achieved well if the students have good critical thinking skills. It is in accordance with the opinion expressed by A. N. Chukwuyenum (2013) stated that critical thinking is also an effective way to improve student's understanding of the mathematical concepts. Thus, HOTS assessment indirectly contributes positively learning to improve understanding of the mathematical concepts. 
Problem-solving skill is an important aspect of critical thinking skills. HOTS Assessment presents contextual issues that encourage students to analyze a contextual problem and solve it using the knowledge learned in the classroom. The presentation of the contextual problems can also increase student's motivation to learn. The contextual problems can be related to the theoretical knowledge in the classroom with the daily life situation. What if the students can solve the problems around them using the knowledge gained in the classroom, then HOTS assessment indirectly can increase student's interest in learning. Thus, HOTS assessment can improve the learning quality in the classroom. HOTS assessment presents issues that require the skills to make decisions in solving specific problems. In certain cases, students are faced with several alternatives to choose to get the best solution among the alternatives. In addition, HOTS assessments also present problems that can be solved in many ways. In this case, the students are required to have divergent thinking skills. HOTS assessment can train students to incorporate some existing strategies into new strategies or create a strategy that has never really existed before. Thus, HOTS assessment can improve important aspects of critical thinking skills. Therefore, it is very reasonable that student's critical thinking skills in the mathematics subjects of the learner's group using HOTS assessment is better than LOTS assessment group. It is due to the trained skills of student's critical thinking through using HOTS assessment.

HOTS assessment presents non-routine issues. The presentation of problems that are not routinely aimed at exploring student's creative ideas to analyze and solve new problems. Creative ideas of the students will grow and develop along with the improvement of critical thinking skills they have. HOTS Assessment is able to describe the extent to which student's critical thinking skills. It can be seen from student's skills to analyze problem-solving, linking various information in stimulus in the problem, including integrated concepts to formulate problem-solving for the conclusion.

In control group, student's critical thinking skills in the mathematics subjects using LOTS assessment is lower than student's group following HOTS assessment. LOTS assessment tends to emphasize on memorizing, arithmetic calculations of numbers or a small portion of the concepts application on routine issues, provide only temporary and ineffective knowledge to develop critical thinking skills. LOTS assessment is incapable of grabbing aspects of critical thinking skills in math subjects. Therefore, the aspects of student's critical thinking skill are not well-honed. Thus impacting on the student's skill to solve problems that demand high-level thinking skills. Thus, it is natural that the student's critical thinking skills who follow the lesson with LOTS assessment are lower than the student's critical thinking skills following HOTS assessment in the experimental group.

\section{Conclusion}

Based on the above description, it can be concluded that the use of HOTS assessment in mathematics learning has a significant effect on student's critical thinking skills in learning mathematics. Thus, the use of HOTS assessment in mathematics learning is proven to effectively improve student's critical thinking skills, unlike HOTS assessments can train and develop important aspects of critical thinking skills. Therefore, it is suggested to math teachers using HOTS assessment as an alternative assessment to improve student's critical thinking skill, especially in mathematics learning at the high school level.

\section{Acknowledgements}

Our deep and sincere gratitude were presented to God for having granted us the ability and the opportunity to complete this paper. We would also like to thank our former lecturers and our friends for their support, their patience, their contribution, and their valuable input, therefore, this article could be completed. Dreadful thanks to I Wayan Subaga, vice principal of SMA Negeri 8 Denpasar who has given permit of research and data needed. Therefore, the research is able to be completed. Thanks to all students of XII-IPA grade class in SMA Negeri 8 Denpasar for their participating and sincerity. We would also thank I Wayan Suryasa as an advisor as well as editor in chief of IJCU, IJMRA, SKIREC, Euro Asia as well as ScienceScholar who has reviewed and approved this study to be published.

Widana, I., Parwata, I., Parmithi, N., Jayantika, I., Sukendra, K., \& Sumandya, I. (2018). Higher Order Thinking Skills Assessment towards Critical Thinking on Mathematics Lesson. International Journal Of Social Sciences And Humanities (IJSSH), 2(1), 24-32. doi:10.29332/ijssh.v2n1.74 


\section{References}

1. Brookhart, S. M. (2010). How to assess higher-order thinking skills in your classroom. ASCD. View in (Google Scholar)

2. Chukwuyenum, A. N. (2013). Impact of critical thinking on performance in mathematics among senior secondary school students in Lagos state. IOSR Journal of Research \& Method in Education, 3(5), 18-25. View in (Google Scholar)

3. Abdullah, I. H. (2016). Berpikir kritis matematik. Delta-Pi: Jurnal Matematika dan Pendidikan Matematika, 2(1).

View in (Google Scholar)

4. Kulbir, S. S. (2006). The teachers of Mathematics.

View in (Google Scholar)

5. Lai, E. R., \& Viering, M. (2012). Assessing 21st century skills: Integrating research findings. In annual meeting of the National Council on Measurement in Education, Vancouver, BC, Canada.

View in (Google Scholar)

6. National Education Association. (2012). Preparing 21st century students for a global society: An educator's guide to the "Four Cs". Alexandria, VA: National Education Association.

View in (Google Scholar)

7. Sri Hastuti, N. (2009). Peningkatan Kemampuan Berpikir Kritis Matematis Siswa Smp Melalui Pembelajaran Berbasis Masalah. In Seminar Nasional Matematika dan Pendidikan Matematika 2009. Jurusan Pendidikan Matematika FMIPA UNY.

View in (Google Scholar)

8. Paul, R., \& Elder, L. (2001). The miniature guide to critical thinking: Concepts \& tools. Foundation Critical Thinking.

View in (Google Scholar)

9. Pendidikan, P. M., \& Nomor, K. R. I. (59). Tahun 2014 tentang Kurikulum 2013 Sekolah Menengah Atas. Madrasah Aliyah.

View in (Google Scholar)

10.Peter, E. E. (2012). Critical thinking: Essence for teaching mathematics and mathematics problem solving skills. African Journal of Mathematics and Computer Science Research, 5(3), 39-43.

View in (Google Scholar)

11. Germaine, R., Richards, J., Koeller, M., \& Schubert-Irastorza, C. (2016). Purposeful Use of 21st Century Skills in Higher Education. Journal of Research in Innovative Teaching, 9(1).

View in (Google Scholar)

12. Rotherham, A. J., \& Willingham, D. (2009). 21st century. Educational leadership, 67(1), 16-21.

View in (Google Scholar)

13. Sunaryo, Y. (2013). Model pembelajaran berbasis masalah untuk meningkatkan kemampuan berpikir kritis dan kreatif matematik siswa sma di kota tasikmalaya (Doctoral dissertation, Universitas Terbuka). View in (Google Scholar)

14. Widana, I. W. (2016). Penulisan Soal HOTS untuk Ujian Sekolah. Jakarta: Direktorat Pembinaan SMA. View in (Google Scholar) 
15. Widana, I. W. (2017). Higher Order Thinking Skills Assessment (HOTS). JISAE: Journal of Indonesian Student Assesment And Evaluation, 3(1), 32-44.

View in (Google Scholar)

16. Maba, W. (2017). Teacher's Perception on the Implementation of the Assessment Process in 2013 Curriculum. International Journal of Social Sciences and Humanities (IJSSH), 1(2), 1-9.

View in (Google Scholar)

17. Maba, W., Perdata, I. B. K., \& Astawa, I. N. (2017). Constructing Assessment Instrument Models for Teacher's Performance, Welfare and Education Quality. International Journal of Social Sciences and Humanities (IJSSH), 1(3), 88-96.

View in (Google Scholar)

18. Suryasa, I. W., Prayoga, I. G. P. A., \& Werdistira, I. W. A. (2017). An Analysis of Students' Motivation Toward English Learning As Second Language Among Students In Pritchard English Academy (PEACE). International Journal of Social Sciences and Humanities (IJSSH), 1(2), 43-50.

View in (Google Scholar)

19. Suarta, I. M. (2017). Revitalization of Oral Literature Tradition of Balinese Society Based Character Values As Deradicalism Effort. International Journal of Social Sciences and Humanities (IJSSH), 1(3), 816.

View in (Google Scholar)

20. Aini, Z. (2017). The Actualization of cultural elements in novel Guru Onyeh by Salman Faris. International Journal of Social Sciences and Humanities (IJSSH), 1(3), 17-27.

View in (Google Scholar)

21.Garrison, D. R., Anderson, T., \& Archer, W. (1999). Critical inquiry in a text-based environment: Computer conferencing in higher education. The internet and higher education, 2(2-3), 87-105.

View in (Google Scholar)

22. Garrison, D. R., \& Kanuka, H. (2004). Blended learning: Uncovering its transformative potential in higher education. The internet and higher education, 7(2), 95-105.

View in (Google Scholar)

23.Zohar, A., Degani, A., \& Vaaknin, E. (2001). Teachers' beliefs about low-achieving students and higher order thinking. Teaching and Teacher Education, 17(4), 469-485.

View in (Google Scholar)

24.Zohar, A. (1999). Teachers' metacognitive knowledge and the instruction of higher order thinking. Teaching and teacher Education, 15(4), 413-429.

View in (Google Scholar)

25. Rosas, R., Nussbaum, M., Cumsille, P., Marianov, V., Correa, M., Flores, P., ... \& Rodriguez, P. (2003). Beyond Nintendo: design and assessment of educational video games for first and second grade students. Computers \& Education, 40(1), 71-94.

View in (Google Scholar)

Widana, I., Parwata, I., Parmithi, N., Jayantika, I., Sukendra, K., \& Sumandya, I. (2018). Higher Order Thinking Skills Assessment towards Critical Thinking on Mathematics Lesson. International Journal Of Social Sciences And Humanities (IJSSH), 2(1), 24-32. doi:10.29332/ijssh.v2n1.74 


\section{Biography of Author}

\begin{tabular}{|l|l||}
\hline I Wayan Widana is an associate professor of Mathematics Program Studies, Faculty of \\
Mathematics and Natural Sciences Education, Teacher Training Institute and Education \\
Sciences of PGRI Bali. He graduated his bachelor degree in Jakarta State University in \\
research and education evaluation. He finished his master degree in Ganesha Education \\
University on research and education evaluation. He completed his doctoral degree at \\
Terbuka University, Jakarta. He has been published some books with ISBN in learning \\
and education field as well as authored some modules. \\
Email: i.wayan.widana.bali@ gmail.com
\end{tabular}

